\title{
PELAKSANAAN KEGIATAN PROJEK PERCEPATAN PELAKSANAAN \\ PENDAFTARAN TANAH SISTEMATIS LENGKAP (PTSL) DI DESA \\ SUKOBUBUK KECAMATAN MARGOREJO KABUPATEN PATI
}

\author{
Sofi Alawiya, Kristiyanto dan Anggit Wicaksono \\ Email : sofi_alawiya@gmail.com,kristiyanto@umk.ac.id, \\ anggit.wicaksono@umk.ac.id \\ Fakultas Hukum Universitas Muria Kudus
}

\begin{abstract}
ABSTRAK
Program Percepatan Pelaksanaan Pendaftaran Tanah Sistematis Lengkap (PTSL), adalah kegiatan yang diselenggarakan oleh pemerintah di bidang pertanahan pada umumnya dan di bidang pendaftaran tanah pada khususnya, yang berupa pensertifikatan tanah yang dilaksanakan secara serentak bersama-sama (massal) dan penyelesaian sengketa-sengketa tanah yang bersifat strategis. Salah satu desa yang mendapatkan projek PTSL adalah Desa Sukobubuk. Desa Sukobubuk mendapatkan jatah 200 bidang tanah dalam PTSL, dari hasil laporan PTSL 2017 Desa Sukobubuk paling bagus dalam membuat hasil laporan PTSL.
\end{abstract}

Kata Kunci : Pendaftaran Tanah, PTSL, Desa Sukobubak, Kabupaten Pati 


\section{PENDAHULUAN}

Bumi, air dan ruang angkasa demikian pula segala kekayaan alam yang terkandung di dalamnya adalah merupakan suatu karunia dari Tuhan Yang Maha Esa kepada seluruh rakyat Indonesia dan oleh karena itu, sudah semestinya pemanfaatan fungsi bumi, air dan ruang angkasa beserta segala apa yang terkandung di dalamnya adalah ditujukan untuk mencapai sebesarbesarnya kemakmuran seluruh rakyat Indonesia.

Tanah merupakan permukaan bumi yang merupakan tempat manusia hidup dan berkembang serta mencari sumber nafkah sampai dengan sebagai tempat bersemayam ketika berpulang ke rahmatullah. G. Kartasaputra menyatakan pentingnya arti tanah bagi kehidupan manusia karena manusia itu sama sekali tidak dapat dipisahkan dari tanah. $^{24}$ Demikian pentingnya tanah bagi kehidupan manusia, karenanya tidak mengherankan kalau setiap manusia ingin memiliki atau menguasainya, yang berakibat timbulnya masalah-masalah tanah, yang kerap kali menimbulkan perselisihan.

Pada tahun 2017 berdasarkan Peraturan Menteri Agraria dan Tata Ruang/ Kepala Badan Pertanahan Nasional Republik Indonesia Nomor 1 Tahun 2017, disusunlah Program Percepatan Pelaksanaan Pendaftaran Tanah Sistematis Lengkap (PTSL) adalah kegiatan

yang diselenggarakan oleh pemerintah di bidang pertanahan pada umumnya dan di bidang pendaftaran tanah pada khususnya, yang berupa pensertifikatan tanah yang

\footnotetext{
${ }^{24}$ G. Kartasaputra, Hukum Tanah Jaminan Bagi Keberhasilan Pendayagunaan Tanah, PT. Raja Grafindo Persada, Jakarta, 1991, hlm. 9.
}

dilaksanakan secara serentak bersamasama (massal) dan penyelesaian sengketa-sengketa tanah yang bersifat strategis.

Kantor Pertanahan Kabupaten Pati sebagai salah satu Kantor Pertanahan di Propinsi Jawa Tengah pada tahun 2017 telah melaksanakan Program Pelaksanaan Pendaftaran Tanah Sistem Terpadu Lengkap (PTSL) yang sudah direncanakan dengan dukungan dana dari pemerintah pusat dengan Anggaran Pendapatan dan Belanja Negara (disingkat APBN) dengan jumlah bidang tanahnya yang sudah ditentukan / terbatas sesuai Daftar Isi Pelaksanaan Anggaran (selanjutnya disingkat DIPA). Pada Tahun 2017 Kabupaten Pati memperoleh PTSL sebanyak 40.000 (empat puluh ribu) bidang tanah di 20 (dua puluh) kecamatan, yaitu di Kecamatan Batangan, Cluwak, Dukuhseti, Gabus, Gembong, Jaken, Juwana, Kayen, Margorejo, Margoyoso, Pati, Margorejo, Sukolio, Tambakromo, Tayu, Tlogowungu, Trangkil, Wedarijaksa, Winong, Tayu.

Dari total 40.000 (empat puluh ribu) PTSL yang terbagi dalam 2 Tahap PTSL, pada tahap pertama sebanyak 15.000 (lima belas ribu) dan tahap kedua 25.000 (dua puluh lima ribu) di Wilayah Kabupaten Pati. Salah satu desa yang mendapatkan projek PTSL adalah Desa Sukobubuk. Desa Sukobubuk mendapatkan jatah 200 bidang tanah dalam PTSL. Desa ini tergolong berpenduduk sangat padat dengan keadaan masyarakatnya mayoritas ekonomi lemah dan berpendidikan menengah. ${ }^{25}$ Desa

\footnotetext{
${ }^{25}$ Saman, Wawancara Pribadi, Kepala Desa Sukobubuk Kecamatan Margorejo Kabupaten Pati, 23 Januari 2018.
} 
Sukobubuk dipilih peneliti karena dari hasil laporan PTSL 2017 Desa Sukobubuk paling bagus dalam membuat hasil laporan PTSL.

Mengingat pelaksanaan program PTSL merupakan kegiatan Kantor Pertanahan yang berkaitan dengan Instansi lain (Pemerintah Kabupaten Pati, Camat dan Kepala Desa setempat serta Pemohon / masyarakat desa tempat dilaksanakannya program PTSL) maka kesuksesannya dibutuhkan suatu koordinasi dan kinerja yang baik. Berdasarkan hasil review laporan yang paling baik adalah Desa Sukobubuk informasi tersebut penuis dapatkan dari hasil wawancara dengan Nur Rido salah satu petugas ukur di BPN Pati. ${ }^{26}$ Oleh karena itu, untuk mengetahui pelaksanaan PTSL di Desa Sukobubuk tersebut perlu dilakukan penelian dalam rangka penyusunan skripsi, dengan judul : "Pelaksanaan Kegiatan Projek Percepatan Pelaksanaan Pendaftaran Tanah Sistematis Lengkap (PTSL) Di Desa Sukobubuk Kecamatan Margorejo Kabupaten Pati”.

Berdasarkan latar belakang permasalahan tersebut, maka yang menjadi rumusan masalahnya antara lain :

1. Bagaimanakah pelaksanaan Kegiatan PTSL di Desa Sukobubuk Kecamatan Margorejo Kabupaten Pati ?

2. Apa hambatan dan solusi dalam pelaksanaan kegiatan PTSL di Desa Sukobubuk Kecamatan Margorejo Kabupaten Pati tersebut?

\footnotetext{
${ }^{26}$ Nur Rido, Wawancara Pribadi, Petugas Ukur Kantor Pertanahan Kabupaten Pati, 2 Februari 2018.
}

\section{METODE PENELITIAN}

Penelitian ini merupakan penelitian hukum yang menggunakan pendekatan Yuridis Empiris atau biasa disebut juga sebagai Yuridis Sosiologis. Penelitian ini berbasis pada ilmu hukum normatif (peraturan perundangan), tetapi bukan mengkaji sistem norma dalam aturan perundangan, namun mengamati bagaimana reaksi dan interaksi yang terjadi ketika sistem norma itu bekerja di masyarakat. ${ }^{27}$

Menurut tarafnya, penelitian ini dispesifikasikan sebagai penelitian deskriptif analitis. Bersifat deskriptif karena penelitian ini dimaksudkan untuk memberikan gambaran secara rinci, sistematis dan menyeluruh mengenai segala hal yang berhubungan dengan pelaksanaan kegiatan Projek Percepatan Pelaksanaan Pendaftaran Tanah Sistematis Lengkap (PTSL) Di Desa Sukobubuk Kecamatan Margorejo Kabupaten Pati yang selanjutnya dikaji menurut peraturan perundang-undangan yang relevan..

Tehnik penentuan sampel yang digunakan adalah purposive sampling. Purposive sampling diterapkan apabila Peneliti benar - benar ingin menjamin, bahwa unsur - unsur yang hendak ditelitinya masuk ke dalam sample yang ditariknya. ${ }^{28}$

\footnotetext{
${ }^{27}$ Mukti Fajar ND dan Yulianto Achmad, Dualisme Penelitian Hukum Normatif \& Empiris, Pustaka Pelajar, Yogyakarta, 2010, hlm 47.

${ }^{28}$ Soerjono Soekanto, Pengantar Penelitian Hukum, Universitas Indonesia Press, Jakarta,1986, hlm.196.
} 


\section{HASIL PENELITIAN DAN}

PEMBAHASAN

\section{Pelaksanaan Kegiatan PTSL di Desa Sukobubuk Kecamatan Margorejo Kabupaten Pati.}

Program dari pemerintah pusat yaitu Pendaftaran Tanah Sistematis Lengkap yang disingkat dengan PTSL, pada tahun 2017 ini Pemerintah akan membagikan lima juta sertifikat diseluruh wilayah Negara Kesatuan Republik Indonesia. Menteri Agraria Tata Ruang/Badan Pertanahan Nasional Sofyan Djalil menyatakan bahwa wilayah NKRI ini baru 46\% (empat puluh enam persen yang bersertifikat, sementara $54 \%$ (lima puluh empat persen) belum bersertifikat, hal ini ini yang melatarbelakangi adanya pemberian sertifikat gratis dengan diadakan program pemerintah yang dimulai di tahun 2017. ${ }^{29}$

Pelaksanaan pendaftaran hak milik atas tanah secara sistematis lengkap dengan berlakunya peraturan menteri agraria dan tata ruang/ kepala badan pertanahan nasional nomor 1 tahun 2017. Kegiatan Pendaftaran tanah secara sistematis lengkap di Kabupaten Pati baru pertama kali dilaksanakan, mengingat banyak masyarakat di Kabupaten Pati belum mendaftarkan hak atas tanahnya. Kegiatan Pendaftaran Tanah Sistematis Lengkap merupakan agenda yang telah di tetapkan oleh Kantor Pertanahan Kabupaten Pati, untuk membantu masyarakat mendaftarkan hak atas tanahnya. Berikut tahap-tahapan konversi yang dilakukan melalui Kegiatan Percepatan Pelaksanaan Pendaftaran Tanah Sistematis Lengkap.

\footnotetext{
${ }^{29}$ https://jatengprov.go.id/berita-utama/prona bukan-bagi-bagi-sertifikat, diakses 19 Januari 2018.
}

1. Penetapan Lokasi;

2. Pembentukan Panitia Ajudikasi Dibentuk pada tanggal 18 januari 2017 :

a. Ajudikasi;

b. Susunan Panitia Ajudikasi.

3. Penyuluhan;

4. Pembentukan Satuan Tugas Pengumpul Data Yuridis;

5. Pengumpulan Data Yuridis;

6. Pengolahan data yuridis dan Pembuktian Hak;

7. Pemeriksaan Tanah dan pengukuran;

8. Pengumuman;

9. Penerbitan Sertifikat;

10. Penyerahan Sertipikat Penyerahan sertipikat adalah tahapan terakhir dari serangkain kegatan Pendaftaran Tanah Sistematis Lengkap yang dilakukan di Desa Sukobubuk Kecamatan Margorejo Kabupaten Pati.

Peraturan Menteri Agraria dan Tata Ruang/Kepala Badan Pertanahan Nasional Republik Nomor 1 Tahun 2017 tentang Percepatan Pendaftaran Tanah Sistematis Lengkap terlihat jelas bahwa adanya penerapan dari asas tersebut. Secara tertulis dimuat didalam Pasal 2 ayat (2) yang pada intinya mengatakan bahwa adanya program dari pemerintah ini yang berupa Pendaftaran Tanah Sistematik Lengkap yang dilaksanakan untuk memberikan jaminan kepastian hukum dan perlindungan hukum hak atas tanah kepada masyarakat secara pasti yang berupa pemberian sertifikat, dengan prosesnya yang sederhana cepat lancar, aman, adil, merata dan terbuka untuk siapapun tanpa terkecuali dengan memenuhi syarat-syarat yang telah ditentukan dalam peratura perundangundangan serta akuntabel yang mana 
adanya pertanggung jawaban dari penyelenggara program ini.

Pertanggungjawaban dari kegiatan PTSL ini dengan adanya laporan pelaksanaan kegiatan ketika terjadi permasalahan dalam pelaksanaan PTSL dan setelah PTSL selesai dilaksanakan. Adapun laporan ketika terjadi permasalahan dilakukan oleh Ketua Panitia Ajudikasi PTSL kepada kepala Kantor Pertanahan dengan tembusan Direktur Jenderal Hubungan Hukum Keagrarian dan Kelapa Kantor Wilayah BPN. Sementara laporan sat PTSL selesai dilaksanakan secara berjenjang dan berkala dari Kantor Pertanahan, Kepala Kantor Wilayah BPN, dan Menteri dengan menggunakan aplikasi Sistem Kendali Mutu (SKMPP).

\section{Hambatan dan solusi dalam} pelaksanaan kegiatan PTSL di Desa Sukobubuk Kecamatan Margorejo Kabupaten Pati

Hambatan yang terjadi dalam pelaksanaan pendaftaran hak milik atas tanah secara sistematis lengkap tersebut di atas Kantor Pertanahan Kabupaten Pati Hambatan yang terjadi dari Kantor Pertanahan Kabupaten Pati berasal dari
a. Anggaran;
b. Pengukuran;
c. Peristiwa hukum kematian;
d. Perangkat dusun;
e. Masyarakat.

Hambatan yang terjadi dalam Pelaksanaan Pendaftaran Hak Atas Tanah Secara Sistematis Lengkap di Kabupaten Pati mempunyai beberapa hambatan dari segi Kantor Pertanahan, Perangkat dusun, masyarakat, dan hahal yang tidak terduga lainnya

\section{Kesimpulan}

a. Berdasarkan hasil dari penelitian, tahap-tahap pelaksanaan pendaftaran tanah sistematis lengkap dari penetapan lokasi, pembentukan panitia ajudikasi, penyuluhan, pembentukan satuan tugas pengumpul data yuridis, pengumpulan data yuridis, pengolahan data yuridis dan pembuktian hak, pemeriksaan tanah dan pengukuran, pengumuman, penerbitan sertipikat,dan tahap terakhir penyerahan sertifikat maka Pelaksanaan Pendaftaran Hak Milik Atas Tanah Secara Sistematis Lengkap telah sesuai dengan Peraturan Menteri Agraria dan Tata Ruang/ Badan Pertanahan Nasional Nomor 1 Tahun 2017 di Kabupaten Pati, hal tersebut diatur dalam Peraturan Menteri Agraria dan Tata Ruang/ Badan Pertanahan Nasional Nomor 1 Tahun 2017 tentang Percepatan Pelaksanaan Pendaftaran Tanah Sistematis Lengkap pada Pasal 3 ayat (3) menentukan bahwa : percepatan Pelaksanaan Pendaftaran Tanah Sistematis lengkap dilakukan dengan tahapan :

1) Penetapan lokasi kegiatan percepatan pendaftaran tanah sistematis lengkap;

2) Pembentukan Pantia Ajudikasi Percepatan;

3) Pengumpulan data Fisik dan Data Yuridis dibidang tanah;

4) Pembuktian hak serta pembukuan Hak Atas Tanah;

5) Penerbitan sertipikat hak atas tanah, bagi yang memenuhi syarat Tiga Puluh Responden di Dusun Kemirikebo yang mendaftarkan hak milik atas tanahnya telah melakukan pendaftaran dengan tahap-tahap tersebut, dan kegiatan Pendaftaran Tanah Sistematis Lengkap tahun 2017 di Desa Sukobubuk baru sampai Tahap Pengumuman. 
b. Hambatan yang terjadi dalam pelaksanaan pendaftaran hak atas tanah secara sistematis lengkap di Kabupaten Pati mempunyai beberapa hambatan dari segi Kantor Pertanahan, Perangkat dusun dan masyarakat, yaitu:

1) Kantor Pertanahan mengalami kendala dengan kurangnya petugas ukur, solusinya dengan menambah petugas ukur di Kantor Pertanahan.

2) Perangkat dusun mengalami kendala ketika terjadi miskomunikasi dengan petugas ukur dari Kantor Pertanahan, solusinya dengan konfirmasi kepada petugas ukur Kantor Pertanahan ketika tidak bisa mendampingi pengukuran di desa.

3) Masyarakat mengalami kendala terkait pengisian blangko persyaratan pengajuan PTSL, solusinya pengisian blangko diisi oleh Perangkat Desa.

\section{Saran}

a. Kepada Pemerintah Pusat dalam hal ini Kementrian ATR/BPN hendaknya menambah anggaran pelaksanaan PTSL dan menambah petugas BPN karena dengan adanya program PTSL petugas BPN kualahan dalam melaksanakan tugasnya dan penambahan anggaran digunakan untuk mengcover biaya yang tidak terduga dalam pelaksanaan PTSL.

b. Kepada BPN Kabupaten Pati hendaknya meningkatkan kinerja pegawai dalam pelaksanaan program PTSL di Kabupaten Pati.

c. Kepada Pemerintah Desa Sukobubuk hendaknya lebih pro aktif dan memberikan dukungan terhadap pelaksanaan program PTSL dengan ikut andil membantu petugas BPN. d. Kepada warga Desa Sukobubuk hendaknya berperan aktif dan memanfaatkan program PTSL agar pelaksanaan PTSL dapat berjalan dengan lancar dan warga mendapatkan haknya berupa sertifikat hak milik sehingga memberi kepastian hukum bagi pemiliknya.

\section{DAFTAR PUSTAKA}

Adrian Sutedi, 2012, Peralihan Hak Atas Tanah dan Pendaftarannya, Sinar Gafika, Jakarta.

Djoko Prakoso, Budiman Adi Purwanto, 1985, Eksistensi PPPTSL sebagai Pelaksanaan Mekanisme Fungsi Agraria, Ghalia Indonesia, Jakarta.

G. Kartasaputra, 1991, Hukum Tanah Jaminan Bagi Keberhasilan Pendayagunaan Tanah, PT. Raja grafindo Persada, Jakarta.

Jayadi Setiabudi, 2012, Tata Cara Mengurus Tanah, Rumah Serta Segala Perizinannya, Suka Buku, Jakarta.

Ronny Hanitijo Soemitro, 1994, Metodologi Penelitian Hukum dan Jurimetri, Ghalia Indonesia, Jakarta.

Soerjono Soekanto, 1981, Pengantar Penelitian Hukum, Universitas Indonesia, Jakarta.

Subarsono, 2005, Mata Kuliah Kebijakan Publik, Program Magister Administrasi Publik 
Sekolah Pasca Sarjana UGM, Yogyakarta.

Urip Santoso, 2010, Pendaftaran dan Peralihan Hak Atas Tanah, Kencana Prenada Media Group, Jakarta.

\section{Peraturan Perundang-Undangan :}

1. Undang-Undang No. 5 Tahun 1960 Tentang Peraturan Dasar Pokok Agraria (Undang-Undang Pokok Agraria);

2. Peraturan Pemerintah Nomor 24

Tahun 1997 Tentang Pendaftaran Tanah Peraturan Pemerintah tersebut merupakan pelaksaan dari Pasal 19 Undang-Undang Pokok Agraria;

3. Peraturan Menteri Agraria dan Tata Ruang Nomor 28 Tahun
2016 tentang Percepatan Program

Nasional Agraria Melalui

Pendaftaran Tanah Sistematis.

4. Peraturan Menteri Agraria dan Tata Ruang Nomor 35 Tahun 2016 tentang Percepatan Pelaksanaan Pendaftaran Tanah Sistematis Lengkap.

5. Peraturan Menteri Agraria dan Tata Ruang Nomor 1 Tahun 2017 tentang Percepatan Pelaksanaan Pendaftaran Tanah Sistematis Lengkap.

\section{Internet}

https://jatengprov.go.id/berita-utama/ prona-bukan-bagi-bagi-sertifikat, diakses 19 Januari 2018. 